University of Nebraska - Lincoln

DigitalCommons@University of Nebraska - Lincoln

USDA National Wildlife Research Center - Staff Publications
U.S. Department of Agriculture: Animal and Plant Health Inspection Service

2012

\title{
Evaluation of elevated bait trays for attracting blackbirds (Icteridae) in central North Dakota
}

\author{
George M. Linz \\ USDA/APHIS/WS National Wildlife Research Center, george_m_linz@yahoo.com \\ Jamison B. Winter \\ North Dakota State University \\ William J. Bleier \\ North Dakota State University, William.Bleier@ndsu.nodak
}

Follow this and additional works at: https://digitalcommons.unl.edu/icwdm_usdanwrc

Part of the Natural Resources and Conservation Commons, Natural Resources Management and Policy Commons, Other Environmental Sciences Commons, Other Veterinary Medicine Commons, Population Biology Commons, Terrestrial and Aquatic Ecology Commons, Veterinary Infectious Diseases Commons, Veterinary Microbiology and Immunobiology Commons, Veterinary Preventive Medicine, Epidemiology, and Public Health Commons, and the Zoology Commons

Linz, George M.; Winter, Jamison B.; and Bleier, William J., "Evaluation of elevated bait trays for attracting blackbirds (Icteridae) in central North Dakota" (2012). USDA National Wildlife Research Center - Staff Publications. 1159.

https://digitalcommons.unl.edu/icwdm_usdanwrc/1159

This Article is brought to you for free and open access by the U.S. Department of Agriculture: Animal and Plant Health Inspection Service at DigitalCommons@University of Nebraska - Lincoln. It has been accepted for inclusion in USDA National Wildlife Research Center - Staff Publications by an authorized administrator of DigitalCommons@University of Nebraska - Lincoln. 


\title{
Evaluation of elevated bait trays for attracting blackbirds (Icteridae) in central North Dakota
}

\author{
George M. Linz ${ }^{\mathrm{a}, *}$, Jamison B. Winter ${ }^{\mathrm{b}}$, William J. Bleier ${ }^{\mathrm{b}}$ \\ ${ }^{a}$ U.S. Department of Agriculture, Wildlife Services, National Wildlife Research Center, 2110 Miriam Circle, Suite B, Bismarck, ND 58501, USA \\ ${ }^{\mathrm{b}}$ Department of Biological Sciences, North Dakota State University, Fargo, ND 58108, USA
}

\section{A R T I C L E I N F O}

\section{Article history:}

Received 9 March 2012

Received in revised form

14 May 2012

Accepted 16 May 2012

\section{Keywords:}

Avicide

Bait trays

Blackbirds

DRC-1339

Sunflower damage

Population management

\begin{abstract}
A B S T R A C T
Sunflower (Helianthus annuus L.) became an economically important crop in North Dakota in the 1970s, providing a major source of food for post-breeding blackbirds (Icteridae). Reducing local blackbird populations with rice grains treated with an avicide is one proposed alternative for reducing sunflower damage. In fall 2007 and 2008, we evaluated the idea of attracting blackbirds to rice-baited trays attached to wire cages supplied with live blackbirds. During our observations (1011 h), we saw 3888 birds, consisting of 25 species and 12 families, on the bait trays. Blackbirds made up $90.4 \%$ of the bird observations, whereas sparrows (Emberizidae) made up 1.6\% of the birds observed. Overall risk to nontarget species appeared minimal. The bait trays, however, attracted a small number of blackbirds compared to the source population feeding in nearby crop fields. Our results strongly suggest DRC-1339treated rice used on bait trays is unlikely to be a cost-effective method of reducing blackbird damage to ripening sunflower.
\end{abstract}

Published by Elsevier Ltd.

\section{Introduction}

\subsection{Sunflower and blackbirds}

Sunflower (Helianthus annuus L.) growers in North Dakota planted an average of $50 \%$ (443,000 ha) of the U.S. crop in 2007 and 2008 (NASS, 2011). Production was estimated at 683,200 t and valued at \$US325 million dollars (@US $0.475 \mathrm{~kg}^{-1}$ ). From August through October, about 75 million blackbirds (Icteridae) migrate through the northern Great Plains, where dense hybrid cattail (Typha $\times$ glauca, Godr.) stands serve as roost units and nearby crops provide ample food (Peer et al., 2003; Linz et al., 2011). Roost size can vary from a few birds to $>70,000$ blackbirds, with wetlands containing $>20,000$ birds common near ripening sunflower (Linz and Homan, 2011). Blackbirds eat some insects and weed seeds but prefer ripening sunflower achenes, especially during the dough stage of development (Cummings et al., 1989; Linz et al., 2011). High-energy food is necessary to facilitate the rapid accumulation of fat reserves during annual feather replacement and prior to migration (Bonier et al., 2007).

State-wide estimates developed from field surveys and bioenergetics models show economic losses are consistently between

\footnotetext{
* Corresponding author. Tel.: +1 701250 4469; fax: +1 7012504408.

E-mail address: george.m.linz@aphis.usda.gov (G.M. Linz).
}

US\$5.0 and \$10.0 million, but these numbers are dependent on the value of the crop (Peer et al., 2003; Klosterman, 2011). Klosterman (2011) found that $12 \%$ of sunflower fields received damage greater than $5 \%$, a level considered worthy of expenditure on bird management tools (Linz and Homan, 2011). Under high damage scenarios, growers either abandon the crop in favor of less vulnerable crops or attempt to use nonlethal methods, often with inconsistent results (Conover, 2002; Linz et al., 2011). It is not surprising, therefore, that growers have asked federal and university scientists to find a method of reducing blackbird populations.

\subsection{DRC-1339 avicide}

In the 1960s, the U.S. Fish and Wildlife Service developed DRC1339 (a.i., 3-chloro-p-toluidine hydrochloride, also 3-chloro-4methylbenzenamine hydrochloride), a restricted use pesticide, to reduce European starling (Sturnus vulgaris L.) populations in feedlots and dairies (DeCino et al., 1966). Researchers found that DRC1339 was highly toxic to a number of pest species including starlings, blackbirds, and corvids (Eisemann et al., 2003). On the other hand, most sparrows (Emberizidae) found around bait units are resistant to the product (Eisemann et al., 2003). Birds rapidly metabolize DRC-1399, which reduces the chances of secondary poisoning of predators and scavengers (Eisemann et al., 2003). In 1989 and 1990, Glahn and Wilson (1992) successfully tested the use of DRC-1339-treated rice grains for reducing local populations of 
blackbirds in Louisiana. Since then, DRC-1339-treated rice grains have been used operationally to protect sprouting rice in Louisiana (Cummings et al., 2005).

Learning of this apparent success in Louisiana, sunflower growers asked researchers to evaluate DRC-1339 for reducing spring migrating and post-breeding blackbirds. Linz et al. (2003) tested the use of DRC-1339-treated rice grains during spring migration in South Dakota and found that blackbirds readily accepted baits in test plots. Cost-benefit analyses showed, however, that costs outweighed the benefits of conducting an operational baiting campaign (Blackwell et al., 2003).

Even so, sunflower producers remained supportive of DRC-1339 as a management tool, reasoning that applying DRC-1339-treated rice grains directly in sunflower fields might be the solution to bird damage. To test this idea, Linz and Bergman (1996) and subsequently, Linz et al. (2000) placed DRC-1339-treated rice baits on the ground in ripening sunflower fields near blackbird roosting units. In both studies, bird damage did not differ between baited and unbaited fields. They concluded that enticing blackbirds to feed on the ground when ripening sunflower was available was a major obstacle to the implementation of this baiting strategy. Additionally, numerous granivorous non-blackbird species use ripening sunflower fields for food and cover (Hagy et al., 2010). Some of these species (e.g., ring-necked pheasants, Phasianus colchicus L.; mourning doves, Zenaida macroura L.) are susceptible to low DRC1339 dosages (Eisemann et al., 2003).

In 2007 and 2008, we attempted to attract blackbirds feeding in ripening sunflower fields to food trays attached to the top of wire cages supplied with live blackbirds (henceforth 'bait units'). Our aim was to assess avian use of rice baits across the sunflower ripening period throughout daylight hours. These data will help provide insight into the most efficient time to bait blackbirds, as well as timing for avoidance of non-target species. We hypothesized that the decoy blackbirds would attract conspecifics, while reducing the risk of non-blackbird exposure to DRC-1339-treated baits.

\section{Materials and methods}

We selected our study area based on historical knowledge of sunflower planting patterns, crop phenology, and blackbird damage to sunflower in North Dakota. We chose Barnes, Griggs, Nelson, Ramsey, Stutsman, and Walsh counties in central North Dakota, which lie within the Prairie Pothole Region (PPR) of North Dakota (Ralston et al., 2007). The vegetation of the region was once tall- or mixed-grass prairies; however, farmers now use the land for small grains, soybean, corn, sunflower, hay, and pasture (NASS, 2011).

\subsection{Bait sites}

Our selection of bait sites was guided by the requirements of the U.S. Environmental Protection Agency label titled Compound DRC1339 Concentrate - Staging Areas (EPA Reg. No. 56228-30). That is, baits can be applied only in noncrop "staging areas" associated with nighttime roosting units and must be at least $15.2 \mathrm{~m}$ from water. We dispersed the bait units across the six study counties in close proximity to ripening sunflower fields and wetlands harboring at least 5000 blackbirds.

\subsection{Prebaiting}

We simulated a blackbird-baiting program by following the requirements of the DRC-1339 Staging Area label (EPA Reg. No. $56228-30$ ). We placed $90-180 \mathrm{~g} \mathrm{tray}^{-1}$ of untreated brown rice on the bait trays and checked the supply daily. Prebait must be provided for 3-7 days or until prebait is well accepted. Further, bait locations must be changed to achieve good acceptance by blackbirds species or if non-blackbird species have been observed eating the prebait. We did not use DRC-1339-treated baits during this study.

\subsection{Bait units}

From 15 August to 12 October 2007 and from 3 September to 18 October 2008, we erected bait units near ripening sunflower fields that were located within $1.6 \mathrm{~km}$ of blackbird roosts. In 2007, 51 bait units were associated with 24 roosts and in 2008, 22 bait units were associated with 10 roosts. These dates coincided with the onset of sunflower seed development in mid-August and initiation of sunflower harvest in mid-October. To attract blackbirds from the fields to the bait units, we captured blackbirds in mist nets and placed them in $1.2 \times 1.2 \times 2$-m modified Australian crow (decoy) traps ( $2.5 \times 5$-cm woven wire), with a 0.5 -m drop box and a single $5-\mathrm{cm}$ slit for birds to enter the traps (Winter, 2010). We attached a plywood food tray $(0.6 \times 1.2-\mathrm{m})$, with a $5 \times 5$-cm wood rim, to the top of the trap.

We supplied individual cages with up to 10 decoy blackbirds that we replaced at least every 30 days. We provided the decoy birds fresh food and water daily. In 2007, we wrapped each cage with a small mesh $(1.3 \times 1.3-\mathrm{cm})$ wire to reduce predation of the decoy birds by mammals (largely, raccoons Procyon lotor L.). When available, we placed the bait units near blackbird perch sites (e.g., trees, utility wires). In 2008, we essentially eliminated mammalian predation with a two-strand $12-\mathrm{V}$ electric fence placed around each cage. We also discouraged non-target bird use of the bait trays by cutting the vegetation in a $7.5 \mathrm{~m}$ radius around the bait units or by placing the bait units in tilled fields.

\subsection{Avian monitoring}

We randomly visited the bait units each day between $0.5 \mathrm{~h}$ after sunrise and $1.5 \mathrm{~h}$ before sunset, except when there was steady rain or wind $>24 \mathrm{~km} / \mathrm{h}$. We parked a vehicle about $50 \mathrm{~m}$ from the bait unit and, after a 10-min quiet period, recorded numbers and species of birds perched on the tray for 20-1 min observations. We took a 2-min break between each observation to record data. We used binoculars and spotting scopes to observe the bait trays. If a bird species could not be determined, we recorded genus or, in a few cases, family.

\subsection{Statistical analysis}

We calculated the mean number blackbirds, granivorous nonblackbird species, and non-granivorous species observed on the bait trays during 20-1-min observations collected over $1 \mathrm{~h}$. We calculated means and standard errors for date and time intervals. Date intervals were set at 7-day intervals from 3 September to 18 October and time intervals were sunrise to $2 \mathrm{~h}$ post sunrise, $2 \mathrm{~h}-4 \mathrm{~h}$ post sunrise, $4 \mathrm{~h}$ post sunrise to $4 \mathrm{~h}$ prior to sunset, $4 \mathrm{~h}$ prior to sunset to $2 \mathrm{~h}$ prior to sunset, and $2 \mathrm{~h}$ prior to sunset until sunset. We used Kruskal-Wallis tests to examine the null hypotheses that numbers of blackbirds, granivorous non-blackbirds, and nongranivorous birds were similar among date and time intervals.

\section{Results}

\subsection{7}

In 2007, we observed the bait trays for $534 \mathrm{~h}$ and recorded 968 individual birds, comprised of 12 species (Table 1 ). Of these 
visits, $88 \%$ were red-winged blackbirds (see Table 1 for scientific names), followed by brown-headed cowbirds (3\%), and common grackles $(2 \%)$. Only blackbirds visited $43 \%(n=22)$ of the bait trays whereas, $8 \%(n=4)$ had only non-blackbirds visit, $14 \%$ $(n=7)$ had both blackbirds and non-blackbirds and 35\% $(n=18)$ were not visited by birds. Numbers of blackbirds were statistically different across date intervals $\left(\chi^{2}=101.42\right.$, $\mathrm{df}=6$, $p<0.001$ ), with peak activity occurring in October (Fig. 1) Blackbird numbers also were statistically different across time intervals ( $\left.\chi^{2}=14.74, \mathrm{df}=4, p=0.005\right)$, with maximum numbers occurring in the morning and late afternoon periods (Fig. 2). Granivorous non-blackbird abundances did not differ across date $\left(\chi^{2}=5.82, \mathrm{df}=6, p=0.443\right)$ or time $\left(\chi^{2}=2.17, \mathrm{df}=4, p=0.704\right)$ intervals.

Table 1

Numbers and percentages of avian species observed on rice-baited trays located in central North Dakota from mid-August to mid-October 2007 and 2008.

\begin{tabular}{|c|c|c|c|c|c|c|}
\hline Common name & $\begin{array}{l}\text { Number } \\
2007\end{array}$ & $\begin{array}{l}\text { Percent } \\
2007\end{array}$ & $\begin{array}{l}\text { Number } \\
2008\end{array}$ & $\begin{array}{l}\text { Percent } \\
2008\end{array}$ & $\begin{array}{l}\text { Number } \\
\text { years combined }\end{array}$ & $\begin{array}{l}\text { Percent } \\
\text { years combined }\end{array}$ \\
\hline \multicolumn{7}{|l|}{ Blackbirds } \\
\hline $\begin{array}{l}\text { Red-winged blackbird } \\
\text { (Agelaius phoeniceus L.) }\end{array}$ & 851 & $87.9 \%$ & 2155 & $73.8 \%$ & 3006 & $77.3 \%$ \\
\hline $\begin{array}{l}\text { Common grackle } \\
\text { (Quiscalus quiscula L.) }\end{array}$ & 17 & $1.8 \%$ & 336 & $11.5 \%$ & 353 & $9.1 \%$ \\
\hline $\begin{array}{l}\text { European starling } \\
(\text { Sturnus vulgaris L.) }\end{array}$ & 10 & $1.0 \%$ & 250 & $8.6 \%$ & 260 & $6.7 \%$ \\
\hline $\begin{array}{l}\text { Yellow-headed blackbird } \\
\text { (Xanthocephalus xanthocephalus Bonaparte) }\end{array}$ & 12 & $1.2 \%$ & 111 & $3.8 \%$ & 123 & $3.2 \%$ \\
\hline $\begin{array}{l}\text { Brown-headed cowbird } \\
\text { (Molothrus ater Boddaert) }\end{array}$ & 30 & $3.1 \%$ & 2 & $<0.1 \%$ & 31 & $0.8 \%$ \\
\hline $\begin{array}{l}\text { Brewer's blackbird } \\
\text { (Euphagus cyanocephalus Wagler) } \\
\text { Nonblackbird: Granivorous }\end{array}$ & 0 & & 1 & $0.1 \%$ & 2 & $<0.1 \%$ \\
\hline $\begin{array}{l}\text { Unidentified sparrow } \\
\text { (Emberizidae) }\end{array}$ & 14 & $1.4 \%$ & 7 & $0.2 \%$ & 21 & $0.5 \%$ \\
\hline $\begin{array}{l}\text { Clay-colored sparrow } \\
\text { (Spizella pallida Swainson) }\end{array}$ & 11 & $1.1 \%$ & 1 & $<0.1 \%$ & 12 & $0.3 \%$ \\
\hline $\begin{array}{l}\text { Savannah sparrow } \\
\text { (Passerculus sandwichensis Gmelin) }\end{array}$ & 11 & $1.1 \%$ & 1 & $<0.1 \%$ & 12 & $0.3 \%$ \\
\hline $\begin{array}{l}\text { Song sparrow } \\
\text { (Melospiza melodia Wilson) }\end{array}$ & 7 & $0.7 \%$ & 0 & & 7 & $0.2 \%$ \\
\hline $\begin{array}{l}\text { Harris' sparrow } \\
\text { (Zonotrichia querula Nuttall) }\end{array}$ & 0 & & 5 & $0.2 \%$ & 5 & $0.1 \%$ \\
\hline $\begin{array}{l}\text { American tree sparrow } \\
\text { (Spizella arborea Wilson) }\end{array}$ & 0 & & 2 & $0.1 \%$ & 2 & $<0.1 \%$ \\
\hline $\begin{array}{l}\text { Grasshopper sparrow } \\
\text { (Ammodramus savannarum Gmelin) }\end{array}$ & 1 & $0.1 \%$ & 0 & & 1 & $<0.1 \%$ \\
\hline $\begin{array}{l}\text { Vesper sparrow } \\
\text { (Pooecetes gramineus Gmelin) }\end{array}$ & 1 & $0.1 \%$ & 0 & & 1 & $<0.1 \%$ \\
\hline $\begin{array}{l}\text { Chipping sparrow } \\
\text { (Spizella passerina Bechstein) }\end{array}$ & 0 & & 1 & $<0.1 \%$ & 1 & $<0.1 \%$ \\
\hline $\begin{array}{l}\text { Western meadowlark } \\
\text { (Sturnella neglecta Audubon) } \\
\text { Nonblackbird: Other species }\end{array}$ & 0 & & 1 & $<0.1 \%$ & 1 & $<0.1 \%$ \\
\hline $\begin{array}{l}\text { Cooper's hawk } \\
\text { (Accipiter cooperii Bonaparte) }\end{array}$ & 1 & $0.1 \%$ & 20 & $0.7 \%$ & 21 & $0.5 \%$ \\
\hline $\begin{array}{l}\text { Unidentified hawk } \\
\text { (Accipitridae) }\end{array}$ & 0 & & 9 & $0.3 \%$ & 9 & $0.2 \%$ \\
\hline $\begin{array}{l}\text { Northern flicker } \\
\text { (Colaptes auratus L.) }\end{array}$ & 0 & & 3 & $0.1 \%$ & 3 & $0.1 \%$ \\
\hline $\begin{array}{l}\text { Yellow-rumped warbler } \\
\text { (Dendroica coronata L.) }\end{array}$ & 0 & & 3 & $0.1 \%$ & 3 & $0.1 \%$ \\
\hline $\begin{array}{l}\text { Sharp-shinned hawk } \\
\text { (Accipiter striatus Vieillot) }\end{array}$ & 0 & & 2 & $0.1 \%$ & 2 & $<0.1 \%$ \\
\hline $\begin{array}{l}\text { Barn swallow } \\
\text { (Hirundo rustica L.) }\end{array}$ & 0 & & 2 & $0.1 \%$ & 2 & $<0.1 \%$ \\
\hline $\begin{array}{l}\text { American robin } \\
\text { (Turdus migratorius L.) }\end{array}$ & 0 & & 2 & $0.1 \%$ & 2 & $<0.1 \%$ \\
\hline $\begin{array}{l}\text { Northern harrier } \\
\text { (Circus cyaneus (L.) }\end{array}$ & 0 & & 1 & $>0.1 \%$ & 1 & $<0.1 \%$ \\
\hline $\begin{array}{l}\text { Merlin } \\
\text { (Falco columbarius L.) }\end{array}$ & 0 & & 1 & $<0.1 \%$ & 1 & $<0.1 \%$ \\
\hline $\begin{array}{l}\text { House sparrow } \\
\text { (Passer domesticus L.) }\end{array}$ & 0 & & 1 & $<0.1 \%$ & 1 & $<0.1 \%$ \\
\hline $\begin{array}{l}\text { Unidentified wren } \\
\text { (Troglodytidae) }\end{array}$ & 1 & $0.1 \%$ & 0 & & 1 & $<0.1 \%$ \\
\hline $\begin{array}{l}\text { Say's phoebe } \\
\text { (Sayornis saya Bonaparte) }\end{array}$ & 1 & $0.1 \%$ & 0 & & 1 & $<0.1 \%$ \\
\hline Unknown bird & 0 & & 3 & $0.1 \%$ & 3 & $0.1 \%$ \\
\hline Total & 968 & $100 \%$ & 2920 & $100 \%$ & 3888 & $100 \%$ \\
\hline
\end{tabular}

\footnotetext{
${ }^{\text {a }}$ European starlings were included in the blackbird category because they are an agricultural pest species.
} 


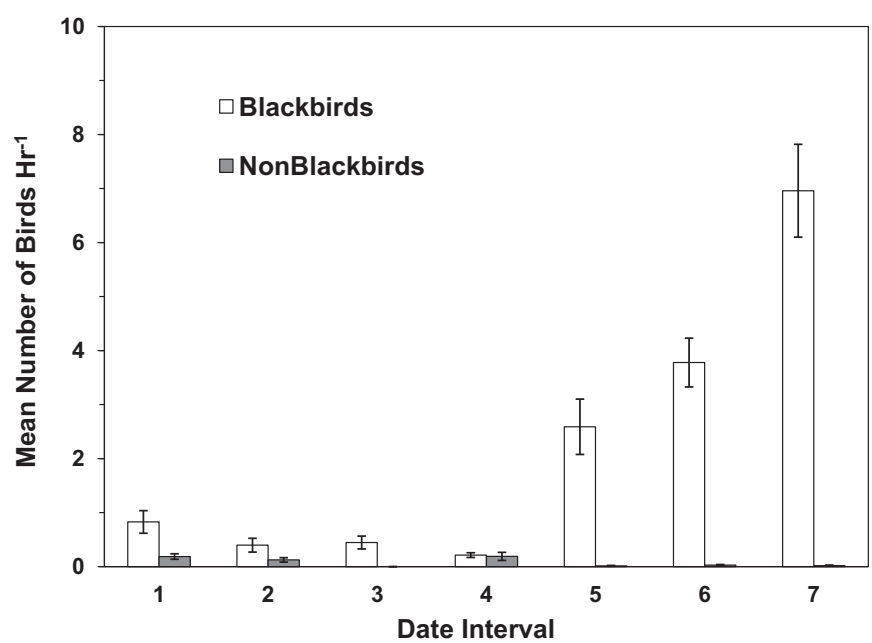

Fig. 1. Means and standard errors of bird numbers $\mathrm{hr}^{-1}$ observed on bait trays during seven one-week date intervals in 2007: Date interval 1: 21-27 August, Date Interval 2: 28 August-3 September, Date Interval 3: 4-10 September, Date Interval 4: 11-17 September, Date Interval 5: 18-24 September, Date Interval 6: 25 September-1 October, Date Interval 7: 2-8 October.

\subsection{8}

In 2008, we observed the bait trays for $487 \mathrm{~h}$ and saw 2920 individual birds, comprised of 20 species. Blackbirds made-up $98 \%$ of these birds, with red-winged blackbirds making up the majority (75\%), followed by common grackles (12\%), and yellow-headed blackbirds $(4 \%)$. In this year, $18 \%(n=4)$ of the bait units had solely blackbirds visit, $72 \%(n=16)$ had blackbird and nonblackbird visits, and $10 \%(n=2)$ had no visiting birds. Blackbird numbers differed across date intervals $\left(\chi^{2}=58.0, \mathrm{df}=5, p<0.001\right)$, with peak activity in late September and early October (Fig. 3). Blackbird abundances also were statistically different across time intervals $\left(\chi^{2}=19.45, \mathrm{df}=4, p<0.001\right)$, with maximum numbers occurring in the morning and late afternoon periods (Fig. 4). Granivorous non-blackbird abundances differed across date intervals $\left(\chi^{2}=12.30, \mathrm{df}=5, p=0.031\right)$ whereas, their numbers did not differ among time intervals $\left(\chi^{2}=2.20, \mathrm{df}=4, p=0.700\right)$ intervals.

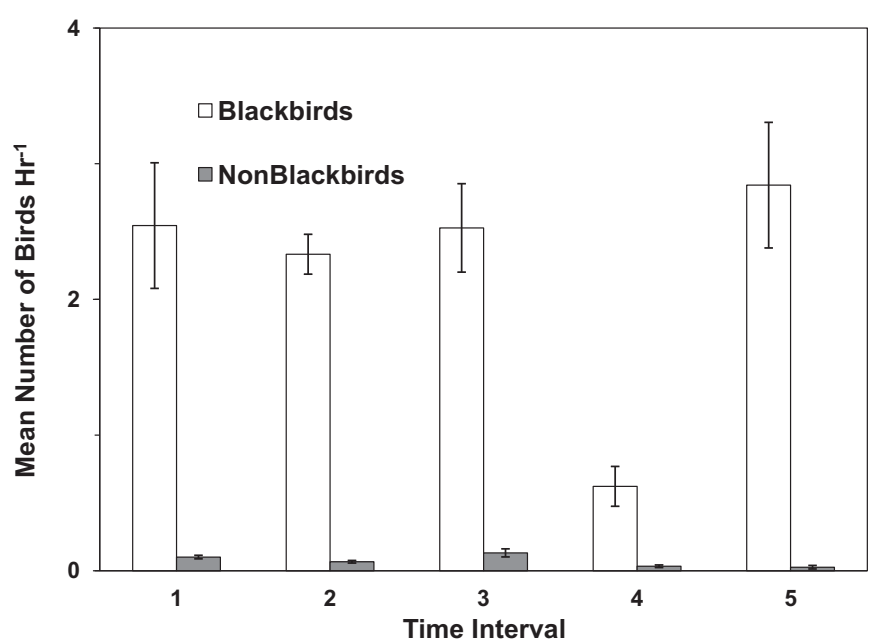

Fig. 2. Means and standard errors of bird numbers $\mathrm{hr}^{-1}$ observed on bait trays during five time-of-day intervals in 2007: Time Interval 1: Sunrise to $2 \mathrm{~h}$ post sunrise, tTime Interval 2: $2-4 \mathrm{~h}$ post sunrise, Time Interval 3: $4 \mathrm{~h}$ post sunrise to $4 \mathrm{~h}$ prior to sunset, Time Interval 4: 4-2 h prior to sunset, and Time Interval 5: $2 \mathrm{~h}$ prior to sunset to sunset.

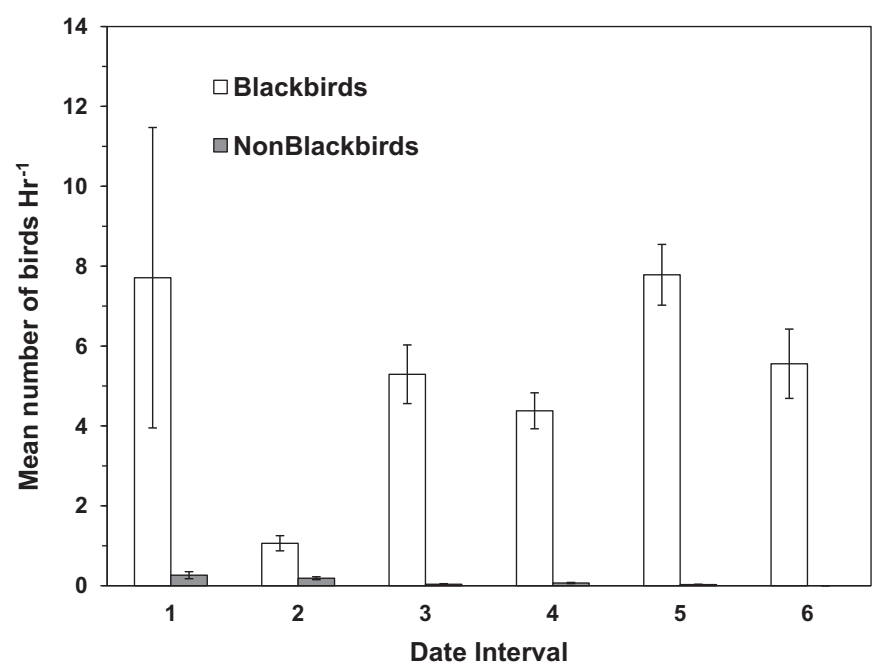

Fig. 3. Means and standard errors of bird numbers $\mathrm{hr}^{-1}$ observed on bait trays during six one-week date intervals in 2008: Date Interval 1: 3-9 September, Date Interval 2: 10-16 September, Date Interval 3: 17-23 September, Date Interval 4: 24-30 September, Date Interval 5:1-7 October, Date Interval 6: 8-14 October.

\section{Discussion}

In late August and early September, during the early ripening phase of sunflower development, we recorded the lowest number of blackbird visits to the bait trays. Cummings et al. (1989) showed that sunflower was most vulnerable to blackbird damage at that time. In comparison, the highest number of blackbird visits was in October, which coincides with sunflower reaching physiological maturity. We witnessed thousands of blackbirds feeding in ripening sunflower fields near our bait units. Thus, it was not surprising that blackbirds dominated the avifauna using the bait trays. Even so, relatively few blackbirds were attracted to the bait trays.

Risk to nonblackbird species appeared to be minimal under the conditions of our study, with sparrows observed most often perching on the bait trays. The DRC-1339 $\mathrm{LD}_{50}$ values associated with granivorous species vary from highly sensitive to insensitive.

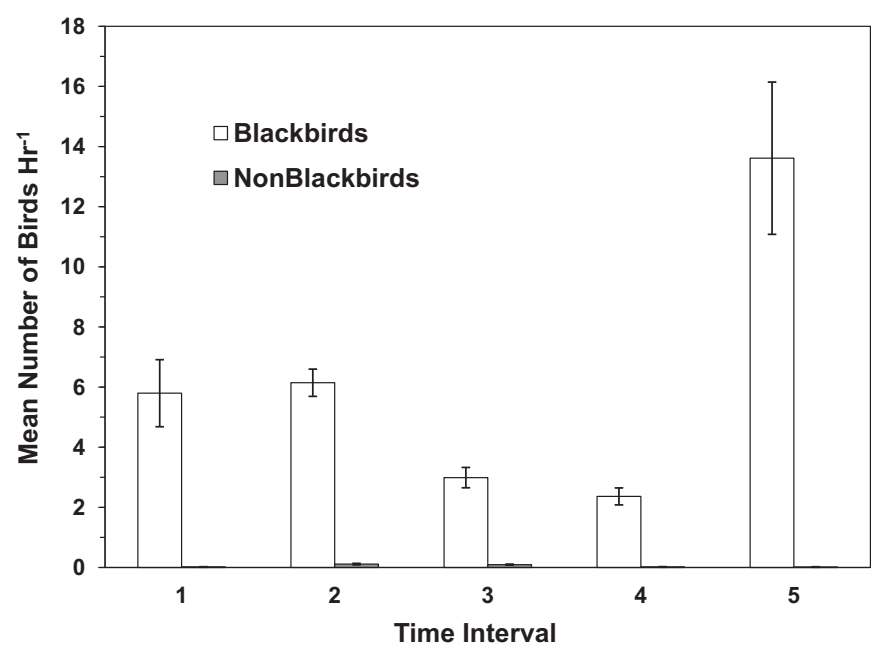

Fig. 4. Means and standard errors of bird numbers $\mathrm{hr}^{-1}$ observed on bait trays during five time-of-day intervals in 2008: Time Interval 1: Sunrise to $2 \mathrm{~h}$ post sunrise, Time Interval 2: $2-4 \mathrm{~h}$ post sunrise, Time Interval 3: $4 \mathrm{~h}$ post sunrise to $4 \mathrm{~h}$ prior to sunset, Time Interval 4: 4-2 h prior to sunset, and Time Interval 5: $2 \mathrm{~h}$ prior to sunset to sunset. 
For example, the $\mathrm{LD}_{50}$ for the dark-eyed junco (Junco hyemalis $\mathrm{L}$.) and American tree sparrow are $162.0 \mathrm{mg} \mathrm{kg}^{-1}$ and $3.5 \mathrm{mg} \mathrm{kg}^{-1}$, respectively (Eisemann et al., 2003). Very sensitive species $\left(L_{50}\right.$ values of $<10 \mathrm{mg} \mathrm{kg}^{-1}$ ) such as meadowlarks and mourning doves (Z. macroura L.) were common in the study area, but no doves and only one meadowlark was observed on a bait tray. Nevertheless, the $\mathrm{LD}_{50}$ data for birds, combined with a host of bird species found in sunflower fields, suggest that a large-scale blackbird-baiting program could prove lethal to some granivorous nonblackbirds (Hagy et al., 2010).

A single brown rice seed treated with DRC-1339 will kill a species sensitive to DRC-1339, while species less sensitive may become lethargic and thus, susceptible to predation by raptors (Kostecke et al., 2001). We did observe red-tailed hawks, Cooper's hawks, sharp-shinned hawks, northern harriers, and merlins perched on the bait units, indicating they were attracted to the decoy blackbirds. Raptors could find DRC-1339 poisoned birds in wetlands and crop fields. However, birds excrete nearly all DRC1339 within $4 \mathrm{~h}$, and most avian predators are tolerant of DRC1339, with oral $\mathrm{LD}_{50}$ values greater than $100 \mathrm{mg} \mathrm{kg}^{-1}$ (Schafer et al., 1983; Eisemann et al., 2003). Thus, the likelihood of a raptor accumulating sufficient DRC-1339 to cause death is remote.

\section{Conclusions and management implications}

We conclude that our experiment with small bait units was not successful. Although portability associated with small cages would be lost, following Meanley's (1971) suggestion of using large decoy traps ( $\sim 12 \mathrm{~L} \times 6 \mathrm{~W} \times 2 \mathrm{H} \mathrm{m}$ ) supplied with many decoys birds $(\geq 15)$ might prove to be more successful at drawing blackbirds to the bait trays. Weatherhead and Greenwood (1981) cautioned, however, that decoy traps tend to attract young birds that are in poor physical condition. These birds might not be capable of inflicting as much damage as older and, presumably better-conditioned birds. Regardless, the costs of maintaining the bait units would require the removal of thousands of blackbirds to be cost-effective. For example, removing one million blackbirds with DRC- 1339 could save growers about US\$70,000 (@US \$0.07 bird yr ${ }^{-1}$; Peer et al., 2003). However, expenditures including salaries and benefits, equipment, supplies and vehicles needed to achieve this result could easily exceed the benefit (Blackwell et al., 2003).

\section{Acknowledgments}

We thank G. Clambey, M. Biondini, S. Travers, and S. Tupper for reviewing an earlier draft of this manuscript. We also thank K. Lash, E. Baumgartner, H. Pruit, M. Kramer, T. Slowik, J. Carlson, and S. Tupper, for assisting with cage fabrication, bird capture, and data collection. P. Mastrangelo provided assistance, equipment, and information on large blackbird roosts and bird damage. The U.S. Geological Survey Banding Laboratory (Master Banding Permit Station \# 21672), U.S. Fish and Wildlife Service (MB019065-3) and North Dakota Game and Fish Department (GNF02238544, GNF02351012) issued pertinent scientific permits. Funding was provided by the North Dakota Crop Protection Product Harmonization and Registration Board, USDA Wildlife Service's National
Wildlife Research Center (NWRC) and the Department of Biological Sciences, North Dakota State University (NDSU). Safety guidelines and animal care were reviewed and approved by the NWRC (Study Protocol QA-1457) and NDSU Institutional Animal Care and Use Committees. Mention of commercial products does not imply endorsement by the U.S. Department of Agriculture or North Dakota State University.

\section{References}

Blackwell, B.F., Huszar, E., Linz, G.M., Dolbeer, R.A., 2003. Lethal control of redwinged blackbirds to manage damage to sunflower: an economic evaluation J. Wildl. Manage. 67, 818-828.

Bonier, F., Martin, P.R., Jensen, J.P., Butler, L.K., Ramenofsky, M., Wingfield, J.C., 2007. Pre-migratory life history stages of juvenile arctic birds: costs, constraints, and trade-offs. Ecology 88, 2729-2735.

Conover, M.R., 2002. Resolving Human-wildlife Conflicts: the Science of Wildlife Damage Management. CRC Press LLC, Boca Raton, Florida, USA.

Cummings, J.L., Guarino, J.L., Knittle, C.E., 1989. Chronology of blackbird damage to sunflowers. Wildl. Soc. Bull. 17, 50-52.

Cummings, J.L., Shwiff, S.A., Tupper, S.K., 2005. Economic impacts of blackbird damage to the rice industry. In: Wildl. Damage Manage. Conf., vol. 11, pp. 317-322.

DeCino, T.J., Cunningham, D.J., Schafer Jr., E.W., 1966. Toxicity of DRC-1339 to starlings. J. Wildl. Manage. 30, 249-253.

Eisemann, J.D., Pipas, P.P., Cummings, J.L., 2003. Acute and chronic toxicity of compound DRC-1339 (3-chloro-4-methylaniline hydrochloride) to birds. In: Linz, G.M. (Ed.), Management of North American Blackbirds. Proceedings of a Special Symposium of the Wildlife Society 9th Annual Conference, 24-28 September 2002, Bismarck, North Dakota, USA, pp. 49-54.

Glahn, J.F., Wilson, E.A., 1992. Effectiveness of DRC-1339 baiting for reducing blackbird damage to sprouting rice. In: Eastern Wildl. Damage Control Conf. vol. 5, pp. 117-123.

Hagy, H.M., Linz, G.M., Bleier, W.J., 2010. Wildlife conservation sunflower plots and croplands as fall habitat for migratory birds. Am. Midl. Nat. 164, 119-135.

Klosterman, M.E., 2011. Assessment of Blackbird Damage to Sunflower and Corn Fields in the Prairie Pothole Region of North Dakota. M.S. thesis. North Dakota State Univ., Fargo.

Kostecke, R.M., Linz, G.M., Bleier, W.J., 2001. Survival of avian carcasses and photographic evidence of predators and scavengers. J. Field Ornithol. 72, 439-447.

Linz, G.M., Bergman, D.L., 1996. DRC-1339 avicide fails to protect ripening sunflowers. Crop Prot. 15, 307-310.

Linz, G.M., Homan, H.J., 2011. Use of glyphosate for managing invasive cattail (Typha spp.) to disperse blackbird (Icteridae) roosts. Crop Prot. 30, 98-104.

Linz, G.M., Homan, H.J., Werner, S.W., Hagy, H.M., Bleier, W.J., 2011. Assessment of bird management strategies to protect sunflower. BioScience 61, 960-970.

Linz, G.M., Knutsen, G.A., Homan, H.J., Bleier, W.J., 2003. Baiting blackbirds (Icteridae) in stubble grain fields during spring migration in South Dakota. Crop Prot 22, 261-264

Linz, G.M., Schaaf, D.A., Wimberly, R.L., Homan, H.J., Pugh, T.L., Peer, B.D., Mastrangelo, P., Bleier, W.J., 2000. Efficacy and potential nontarget impacts of DRC1339 avicide use in ripening sunflower fields: 1999 progress report. In Sunflower Res. Workshop, vol. 22, pp. 162-169.

Meanley, B., 1971. Blackbirds and the Southern Rice Crop. United States Department of the Interior, Bureau of Sport Fisheries and Wildl., Resource Publication 100

National Agricultural Statistics Service (NASS), 2011. January Annual Crop Production Report. http://www.sunflowernsa.com/stats/ (15 January 2012).

Peer, B.D., Homan, H.J., Linz, G.M., Bleier, W.J., 2003. Impact of blackbird damage to sunflower: bioenergetic and economic models. Ecol. Appl. 13, 248-256.

Ralston, S.T., Linz, G.M., Bleier, W.J., Homan, H.J., 2007. Cattail distribution and abundance in North Dakota. J. Aquatic Plant Manage. 45, 21-24.

Schafer Jr., E.W., Bowles Jr., W.A., Hurlbut, J., 1983. The acute oral toxicity, repellency, and hazard potential of 998 chemicals to one or more species of wild and domestic birds. Arch. Environ. Contam. Toxicol. 12, 355-382.

Weatherhead, J.J., Greenwood, H., 1981. Age and condition bias of decoy-trapped birds. Field Ornithol. 52, 10-15.

Winter, J.B., 2010. Avian Use of Rice Baited Trays Attached to Cages with Live Decoy Blackbirds in central North Dakota. MS thesis. North Dakota State Univ., Fargo, USA. 